\title{
On the Necessity of Using Average Cost as a Base for Transfer Price ${ }^{\#}$
}

\author{
Tomáš BUUS* ${ }^{*}$ Jaroslav BRADA**
}

\section{Introduction}

Due to the increasing role of multibusiness enterprises (hereinafter "MBE") and their impact on national welfare, on effectiveness of economic policies and on quality of our lives, we should have interest to clearly and well understand how to deal with transfer pricing issues. Compared to macroeconomic issues, equity premium or many other microeconomic issues, transfer pricing gets much less attention than it deserves. Theory and practice are quite contrary about what shall be optimal transfer price equal to. Our concern will concentrate on the optimal transfer price from the point of view of a MBE, which experiences different income tax rates in countries, where its affiliates have their seats. Former microeconomic literature on transfer prices concludes that optimal transfer price should be equal to marginal cost of production of the supplying business entity (company). This opinion is known since the beginning of the 20th century thanks to (Schmalenbach, 1909) and in Anglo-Saxon literature then (Hirshleifer, 1956). Of course, there are limiting conditions, which are explicitly stated to be held while setting the transfer price that way. On the other hand the conclusion reached in the above mentioned articles could be used in reality only under conditions unable to be met in reality. Other topic of interest is optimal level of transfer price in multinational enterprise with different tax levels in different countries. Either elder or new literature on transfer pricing is mostly based on considering the best transfer price on the level

\footnotetext{
The article is processed as an output of a research project Regulation of Transfer Pricing registered by the Czech Science Foundation under the registration number 402/08/0271.

Ing. Tomáš Buus, Ph.D. - assistant professor; Department of Corporate Finance and Valuation, Faculty of Finance and Accounting, University of Economics, Prague, W. Churchill sq. 4, 13067 Prague, Czech Republic; <buust@vse.cz>.

** Doc. Ing. Jaroslav Brada, Ph.D. - associate professor; Department of Monetary Theory and Policy, Faculty of Finance and Accounting, University of Economics, Prague, W. Churchill sq. 4, 13067 Prague, Czech Republic; <brada@vse.cz>.
} 
of marginal cost. In the first line we could mention pioneering articles (Schmalenbach, 1909) and (Hirshleifer, 1956). Hirshleifer (1957) then extended his solution also for several more realistic situations, but did not abandon marginal cost pricing rule in spite of even previous evidence about different practice (Cook, 1955). Newer publications as (Gatti and Grinnell and Jensen, 1997), (Baldenius and Melumad and Reichelstein, 2004) and (Pappas and Brigham and Hirschey, 1983) or in the Czech literature (Soukup, 2003) or (Novotný, 2008) still consider marginal cost of supplying division as the best solution of the transfer pricing problem.

In (Pappas and Brigham and Hirschey, 1983) authors came to conclusion that the best transfer price in the short run is marginal cost. In long run, however the authors consider to be highly recommendable to use transfer price on free market price level. Baldenius and Melumad and Reichelstein (2004) extend the Hirshleifer's (1956) solution of optimal transfer price in a tax-free world that is the marginal cost of the supplying division, by tax issue. After that these authors argue that: "optimal internal transfer price should be a weighted average of the pre-tax marginal cost and the most favourable arm's length price.” Hirschey (2003) clearly states that optimal transfer price should be set on the level of marginal cost of the supplying division and the same conclusion could be found in many other textbooks on managerial economics. Among significant textbooks noting the marginal cost as the best transfer price in no-tax and no-imperfections world can be also counted (Hirshleifer, 1957). Among the others that argue against transfer price at the marginal cost level and offer another approaches (mainly negotiated transfer prices) are Anctil and Dutta (1999), who advocate for using of negotiated transfer prices. Baldenius and Melumad and Reichelstein (2004) solve the problem of intracompany trade under conditions of monopoly power of supplying division. Market imperfections, differences in marketing cost and smaller risk that receivables would not be paid in intracompany transactions cause that optimal transfer price should be market price minus some discount. Baumol and Bradford (1970) derive departure from marginal cost transfer pricing on the base of taxation needs.

We could mention many other authors, who argue for market prices or negotiated prices, but their argumentation is based on a solution of some specific problem (information asymmetry, solution of investment allocation distortion, agency cost, etc.). The evident collision of the marginal cost transfer pricing theory can be shown in case of (OECD, 2001). The methods of transfer pricing supported in OECD countries are: 
1. arms-length method,

2. cost plus method,

3. comparable resale price method,

4. formula apportionment method,

5. profit split method,

which in all cases directly or indirectly use a premise that the fair transfer price is on the level of price achieved at the market transaction, which are marginal cost only in the extraordinary cases (perfectly competitive market of the intermediate product). If there is no market for intermediate product, the cost-plus method is used, which does not use marginal cost but the average cost of intermediate product. These can be also the optimal solution, which does not require some necessary conditions used or implied by papers deriving the optimality of marginal cost transfer pricing.

However, already Ronen and McKinney (1970) pointed at this problem and showed, that optimal transfer price can be equal to average cost of intermediate product, but this paper is rarely cited and even more rarely are its conclusions used, we rather find marginal cost pricing. Otherwise the contemporary literature aims rather on the information asymmetry, integration of manager's and tax objectives or setting of the optimal transfer price with respect to the particular problems of financial management.

\section{Marginal Cost Transfer Pricing Rule}

Suppose there is a MBE consisting of two companies, A and B, each of which produces one type of good at quantity $q_{A}$, resp. $q_{B}$ for price, which depends on produced quantity, i.e. $p_{A}\left(q_{A}\right)$, resp. $p_{B}\left(q_{B}\right)$ and carry cost $c_{A}\left(q_{A}\right)$ and $c_{B}\left(q_{B}\right)$ related to the production of their products. Company A supplies $B$ with all its products. We do not impose any assumptions about existence of external market of an intermediate product. Company B uses intermediate product of company A to produce its own final product. For simplicity let us consider, that ratio $k$ of products A needed for production of company B is constant and equal to 1 such that $q_{A}=q_{B}$. 
For simplicity we used lower index $i$ instead of A or B. i.e. for we will further denote total revenues $R_{i}\left(q_{i}\right)$, average revenues $r_{i}\left(q_{i}\right)$ and marginal revenues $\rho_{i}\left(q_{i}\right)$; total cost $C_{i}\left(q_{i}\right)$ average cost $c_{i}\left(q_{i}\right)$, and marginal cost $\gamma_{i}\left(q_{i}\right)$. Net marginal revenue $N M R_{i}\left(q_{i}\right)$, where

$$
N M R_{i}\left(q_{i}\right)=\rho_{i}\left(q_{i}\right)-\gamma_{i}\left(q_{i}\right),
$$

First of all we would like to find "appropriate" price $p_{A}\left(q_{A}\right)$, which is called "transfer price" $p_{T}$. To stress importance of this fact, we used sometimes quotation $p_{T}\left(q_{A}\right)$ instead of equivalent $p_{A}\left(q_{A}\right)$. We consider being of use to stress that under $C_{B}\left(q_{B}\right), c_{B}\left(q_{B}\right)$ and $\gamma_{B}\left(q_{B}\right)$ we understand costs of production incurred by company $B$ without influence of price for intermediate product produced by company A.

If we wanted to explicitly state the problem of dependence between cost, prices and quantity, we would have to set

$$
\prod_{A}\left(q_{A}\right)=q_{A} \cdot p_{T}\left(q_{A}\right)-C_{A}\left(q_{A}\right)
$$

and

$$
\prod_{B}\left(q_{A}\right)=q_{A} \cdot p_{B}\left(q_{A}\right)-C_{B}\left(q_{A}\right)-q_{A} \cdot p_{T}\left(q_{A}\right),
$$

which is in fact implicitly understood when we write these equations without this dependency expression, except the fact that transfer price is a function of quantity too (which was omitted by most of the above cited authors, who then came to conclusion that best transfer price is marginal cost of intermediate product). Then necessary condition for achieving of maximal profit of company A and company $\mathrm{B}$ will be reached if derivatives of (2) and (3) are equal to zero, i.e.

$$
\frac{\partial \prod_{A}\left(q_{A}\right)}{\partial q_{A}}=\rho_{A}\left(q_{A}\right)-\gamma_{A}\left(q_{A}\right)=0
$$

and 


$$
\frac{\partial \prod_{B}\left(q_{B}\right)}{\partial q_{B}}=\rho_{B}\left(q_{B}\right)-\gamma_{B}\left(q_{B}\right)-\rho_{A}\left(q_{A}\right)=0 .
$$

However, if we considered transfer price being fixed for all $q_{A}$ or the average cost of intermediate product being constant,

$$
\underset{l \in \Re}{\forall}\left[p_{T}\left(q_{A}\right)=p_{T}\left(q_{A}+l\right) ; c_{A}\left(q_{A}\right)=c_{A}\left(q_{A}+l\right)\right] .
$$

Then, the same way as the above cited authors did, we would get equilibrium of MBE equating (4) and (5) for $\rho_{A}\left(q_{A}\right)$ at

$$
\rho_{B}\left(q_{B}\right)-\gamma_{B}\left(q_{B}\right)=p_{T}\left(q_{A}\right),
$$

while at the same time

$$
\rho_{B}\left(q_{B}\right)-\gamma_{B}\left(q_{B}\right)=\gamma_{A}\left(q_{A}\right),
$$

thus

$$
p_{T}\left(q_{A}\right)=\gamma_{A}\left(q_{A}\right)
$$

for such $q_{A}$, for which (9) holds (let us denote it $q_{A}^{*}$ ).

Let us suppose that the market for intermediate product is perfectly competitive. Under this condition the only solution for price of intermediate product is marginal cost of production of intermediate product, just because of the nature of the market. In the long run all companies sell their production at the lowest possible price - at the minimum of average cost on perfectly competitive market. This average cost is also marginal cost for that given quantity of intermediate product.

If the market for intermediate product were imperfectly competitive, slightly different situation would occur. On the imperfectly competitive market supplying division (company A) could chose any price within range determined by shape and corners of demand curve (of course with regard to its cost function). Nevertheless, marginal cost could be also suitable as a price of intermediate product in this case. Monopoly profit, achieved on the sales of the intermediate product to external consumers enables supplying company not to use its monopoly power in case of 
Buus, T. - Brada, J.: On the Necessity of Using Average Cost as a Base for Transfer Price.

sales to B and set price for intragroup deliveries on the level of marginal cost.

Quite different situation occurs, when market of intermediate product does not exist. In this case there is no external power forcing company A to sell at minimum of average cost and depending upon character of the final product there can or does not have to be space for shifting price of intermediate product.

We have concluded in previous paragraphs that sometimes it is possible to use marginal cost as optimal transfer price in world without taxes (tax differentials), agency cost, etc., but according to our opinion it is particularly due to the fact that external conditions either enable or even force and fix transfer price on such level. We consider marginal cost of intermediate good production not to be good measure for ex ante setting transfer price even in world without taxes and agency cost nor for doing so ex post. The first reason that leads us to this statement is that marginal cost transfer pricing rule distorts resource allocation. The second one is that the above proposed way of transfer pricing would lead to suboptimal decisions in that sense, that it distorts the total cost curve perceived by company selling final product. We will discus both reasons further.

Let us suppose that at the beginning there are one or more non-MBEs. We could assume that profit and cost functions of all firms on the market are the same because of the nature of the perfectly competitive market. Its/their profit functions would be

$$
\Pi^{+}=q_{B} \cdot p_{B}-C_{B}-C_{A},
$$

whereas profit function of MBE as an economic entity would be (if we derived transfer price the above shown way)

$$
\Pi=\left[q_{B} \cdot p_{B}-C_{B}-q_{A} \cdot \gamma_{A}\left(q_{A}^{*}\right)\right]+\left(q_{A} \cdot \gamma_{A}\left(q_{A}^{*}\right)-C_{A}\right),
$$

which after some rearrangements could be written in the same way as (10). Difference between (10) and (11) is in the division of profit between the particular parts of MBE. In (10) revenues are divided according to the factor (labour, capital) cost and those are fully covered by revenues in the single company including both production of $\mathrm{A}$ and $\mathrm{B}$, thus under 
condition of perfect competition on the market of the final product and on the input factor markets economic profit equals zero.

If the transfer price were set on level of marginal cost of supplying division in the case of MBE, revenues could be divided differently from factor cost. This situation would lead either to shifts and change of shape of production and cost functions or, in case that managers realized that inefficiency to backward shifts in profit, compensating wrong transfer price. Let us assume perfectly competitive market of final product in the absence of market for intermediate product.

All companies operate at the lowest possible average cost on the perfectly competitive market, so that if managers of MBE did not realize the inefficiency, changes in the cost functions would lead to complete loss of competitiveness in long run because of inability to acquire either enough capital or enough labour or to produce at competitive price. If we assumed that managers of MBE arrange backward shifting of profit, we would get to the same state as in equation (10), except for the problem that shifting of profit could have non-zero cost (thus again in long run MBE would probably lose ability to compete its rivals). Actually we do not impose the assumption that the backward shifting of profit would have non-zero cost, but we just cannot exclude that possibility. Under absence of market for intermediate product and perfectly competitive market of final product we can say that transfer price at a level of marginal cost is unstable and would earlier or later lead to cease of MBE, if we did not impose additional assumptions causing the MBE's design to have some advantages compared to the single-entity company.

If a market for intermediate good existed, but was not perfectly competitive, the situation would be a bit more complicated, because the optimal level of a transfer price depends among other factors upon characteristics of market of the final product. Transfer price could fall within range of prices, which could also include marginal cost of intermediate good A production, without loss of competitiveness. Would each of those prices be also at level ensuring efficient allocation of resources? We think it would not. Though there is no general solution for this market situation. Even though in this case the best solution for the $\mathrm{MBE}$ is that one, which equates marginal cost of production of intermediate good and net marginal revenue of company B (6), we can see that the best solution is not transfer price at level of marginal cost of intermediate product. 
Fig.1 shows an example how might pricing of company's B product look like, if MBE headquarters used marginal cost transfer pricing rule and economic profit arising from this approach was not shifted back (at perfectly competitive market of final product and absence of market for intermediate product).

Fig. 1: Simulation for different quantities, with parameters

$$
\begin{gathered}
c_{A}=1000+\left(q_{A}-20\right)^{2}+4 \cdot\left(q_{A}-20\right), \\
c_{B}=500+\left(q_{B}-40\right)^{2}+6 \cdot\left(q_{B}-40\right), k=1
\end{gathered}
$$

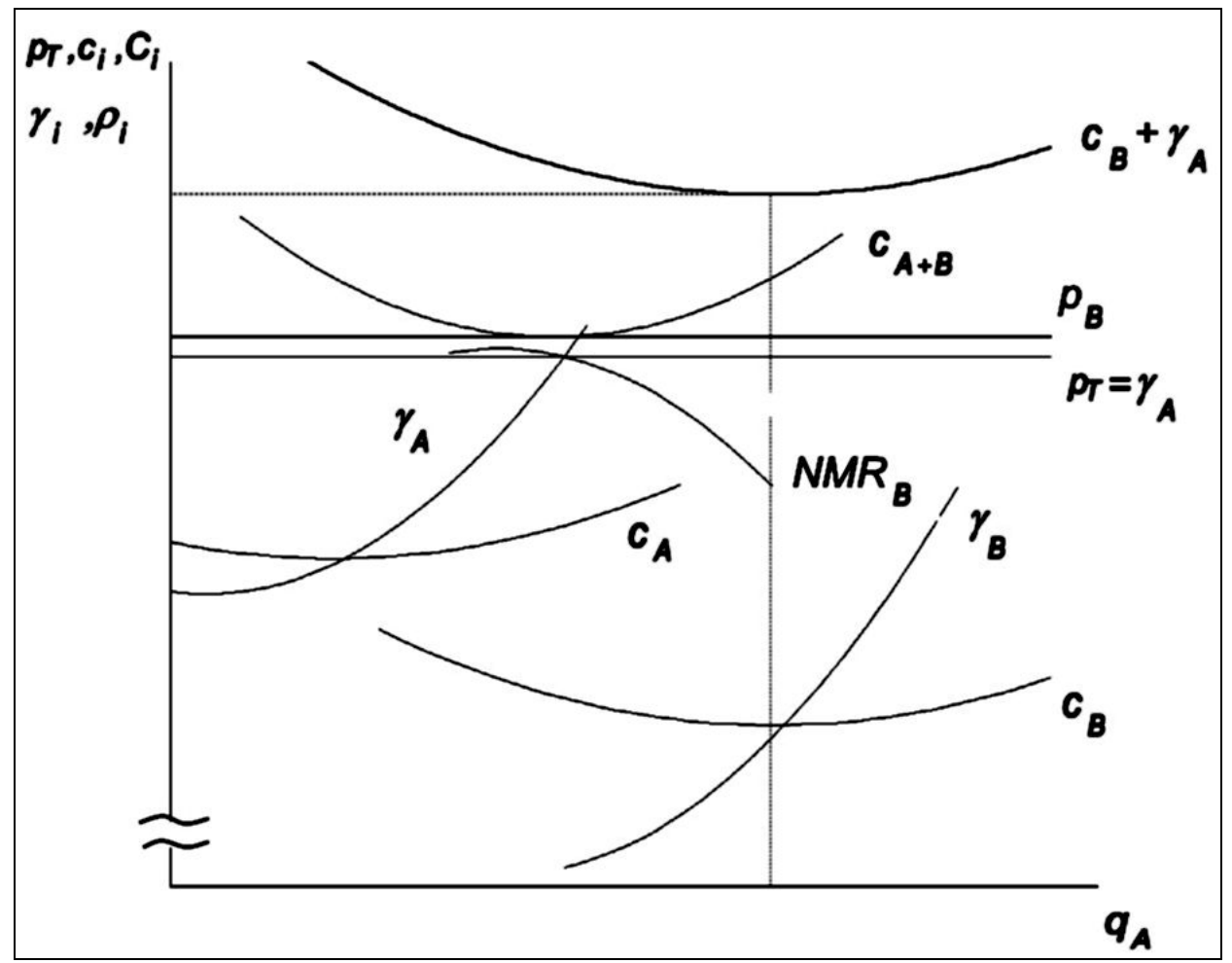

We can see that the marginal transfer pricing rule in our example not only lead to significantly different cost curves, but also to level of output different from the optimal one. The problem about derivation of the marginal transfer pricing rule is that (at least in Hirshleifer's (1956) article) no explicit analysis of the necessary conditions and consequences of setting the transfer price constant can be found. The necessary condition for this solution to be efficient is that average cost of intermediate product is constant for all its quantities (which is rarely 
satisfied in practice). How is it possible that the theory was not tested by simple example or thought experiment? However, reader would probably ask question by what would we like to replace the marginal cost transferpricing rule.

\section{Average Cost Transfer Pricing Rule}

To set the transfer price at the level of average cost seems to be intuitive after considering the properties of profit function of single entity company. It would bear the necessary information about cost of production of intermediate product and allow the price of final product to be divided between divisions $\mathrm{A}$ and $\mathrm{B}$ according to factor cost. The question is whether such a price would not lead to predatory pricing (rivalry) between the divisions, whether it could ensure choice of the equilibrium quantity of production and finally under what conditions it would be a good solution.

Let us abandon the assumption that transfer price has to be constant through all $q_{A}$. Then optimization employed above leads to.

$$
p_{T}\left(q_{A}\right)+q_{A} \cdot \frac{\partial\left[p_{T}\left(q_{A}\right)\right]}{\partial q_{A}}=\gamma_{A}\left(q_{A}\right)
$$

which, being integrated according to $q_{A}$, turns into

$$
p_{T}\left(q_{A}\right)=c_{A}\left(q_{A}\right)+c, c \in R .
$$

As we can see, the approach employed by many previous economists, writing on this matter, led us (with implicit assumption that the constant $c$ is zero) to average cost transfer pricing rule. We just needed to drop the (implicit) assumption that transfer price has to be constant. This pricing rule naturally holds for the optimal quantity $q_{A}^{*}$.

One might argue that this transfer pricing rule would allocate not only variable, but also fixed, cost on a unit of production, inducing division $\mathrm{A}$ to produce as much as possible. This problem is solved by simple design in practice. If the transfer price were set in two parts:

1. variable cost are paid according to the volume of production, 
Buus, T. - Brada, J.: On the Necessity of Using Average Cost as a Base for Transfer Price.

2. fixed cost are paid according to the capital used for production in the particular period,

then (13) holds for every $q_{A}$. In such an arrangement the costing method is full costing, but due to the division into variable and fixed cost it shows signs of variable costing (or rather retrograde costing) and we avoid problems with determination of capacity usage and determination of fixed cost in the intermediate product price. Determination of transfer price in absence of intermediate product market then "reduces" to determination of the acceptable parts or limits of the transfer price. To reduce division A overspending, MBE's headquarters might set an pre-determined level of fixed and variable cost (planned cost). However it is not necessary as under perfect competition at the market for final product there is no space for overspending and it is in the best interest of each division to minimize total cost of final product and in the presence of market for intermediate product company B could chose another supplier, if A was too costly.

There could be several situations on which were discussed above:

1. Market for the intermediate product is perfectly competitive, then $p_{T}$ is exogenous to examined MBE and equal to $\gamma_{A}\left(q_{A}\right)$, i.e. marginal (but also average) cost of intermediate product for the optimal quantity.

2. Market for the intermediate product does not exist and market for the final product is perfectly competitive. The only one price for which the intermediate product could be exchanged between and without lost of efficiency is $p_{T}\left(q_{A}\right)=c_{A}\left(q_{A}\right)$.

3. Market for the intermediate product does not exist and market for the final product is not perfectly competitive (negative slope of demand curve). Then $p_{T}\left(q_{A}\right)=c_{A}\left(q_{A}\right)$ is the lowest possible level for business $A$ and the best possible result of negotiation for $B$. Because of negotiation we can assume that economic profit could be split between $\mathrm{A}$ and $\mathrm{B}$, thus

$$
p_{T}\left(q_{A}\right) \in\left\langle c_{A}\left(q_{A}\right) ; c_{A}\left(q_{A}\right)+\frac{\Pi\left(q_{A}\right)}{q_{A}}\right\rangle .
$$


4. Market for intermediate product exists, but it is not perfectly competitive. The common wisdom tells us that optimal transfer price has to be higher than average variable cost in short run and higher than average cost in long run. Due to the monopoly power A gets some profit from deliveries to external subjects and it can share this profit with B. From the point of view of the selling division (the best result of negotiation) would be:

$$
p_{T}=\frac{\int_{0}^{q_{A}^{*}} N M R(x) d x}{q_{A}^{*}}=\frac{\int_{0}^{q_{A}^{*}}\left[\rho_{B}(x)-\gamma_{B}(x)\right] d x}{q_{A}^{*}},
$$

which is nothing else than

$$
p_{T}=\left(r_{B}-c_{B}\right) .
$$

The worst outcome of transfer price setting from this point of view would be for the supplying company the state when the whole economic profit is allocated to the buying company and $p_{T}\left(q_{A}\right)=c_{A}\left(q_{A}\right)$. Again transfer price could fall into range described by (14). In this case the optimal quantity would be set upon equating marginal cost of production of the intermediate product both to the net marginal revenue and the marginal revenue from selling the intermediate product to economic subjects outside MBE. Previous authors used solution, where the supplying division maximized its profit even on behalf of the buying division. We do not consider this solution to be optimal under every circumstances (e.g. demand elasticities) as supplying division gets economic profit by using monopoly power towards outside buyers and it might be advantageous to subsidize the selling division B with some competitive advantage (in form of lower input cost), which can be used at the market of the final product.

We can consider these levels of transfer price as fully optimal under following conditions (some of them were expressed in the beginning of this article:

1. no tax,

2. no information asymmetry,

3. no need to shift the profit to prevent managers from private consumption on account of a company, 
which are implicitly used or explicitly stated by (Schmalenbach, 1909) and (Hirshleifer, 1956) and of course by most of the modern microeconomics textbooks.

Among other conditions is for instance inability of transfer prices to have signalling function. We seriously doubt about the possibility of transfer price to have signalling function, as mentioned in [15], because transfer prices are mostly unobservable. Signalling function can have only variable that is observable without any distortion to the recipient of the information.

\section{Conclusions and Discussion}

Both older and recent literature on transfer pricing are not unified about the opinion whether the optimal transfer price should be equal to marginal cost of supplying company and set by centralized decision (of a MBE headquarters) or whether it should be set by negotiation or even set on the level of market (arms-length) price. Those, who argue for setting transfer price by negotiation or at the market price levels, base their arguments on market imperfections like information asymmetry, motivation of managers, et cetera. Most of the others replicate Schmalenbach's (1909) derivation of the marginal cost transfer-pricing rule in spite of evident contradiction to economic reality (e.g. Lutter et al., 1987). We have proved that the optimal transfer price should be equal to average cost of the supplying division plus part (or the whole) of economic profit of the $\mathrm{MBE}$, independent on the market conditions at the market of either intermediate or final product. Such a transfer pricing rule can be set either by a holding company, which rules the supplier and buyer of intermediate product, or can be forced by external conditions (in the market for intermediate product). Our solution is suitable in system, where MBE's headquarters sets the transfer-pricing formula and either let the divisions to negotiate about optimal quantity or set it by centralized decision. Though our solution was not entirely new, because Ronen and McKinney (1970) came to similar conclusions, lot of recent papers using marginal cost pricing scheme and the state of contemporary economic textbooks call for paper that would explain under generally acceptable assumptions the disadvantages of marginal cost pricing solution. We also offer a design of full costing mechanism (variable costing) that uses advantages of marginal costing and also advantages of full costing by charging 
separately variable cost (by level of production) and fixed cost (as cost fixed for a given time period).

Several private interviews with CFOs of MBEs have confirmed practical use the above transfer pricing design, but unfortunately the interviewees required absolute confidentiality, so no conclusion could have been drawn on it. At least we should mention the transfer pricing rules by OECD (2001), which are widely applied by tax authorities and use methods, which assume that the transfer price is based on actual average cost of intermediate product.

To avoid overpricing of intermediate product (overspending of supplying division), it would be suitable to use pre-determined (planned) full cost of intermediate product (cp. Miller and Buckman, 1987). Thus this paper allows us to find theoretical concept that would fit and could be extended for examination of transfer pricing policies for taxation (e.g. transfer pricing methods used in OECD, 2001) as well as for managerial purposes.

Although these findings were not solely new, their synthesis as well as generalization of average cost transfer pricing rule were needed as many recent papers still used marginal cost pricing rule without reflecting its unrealistic assumptions.

Our results are applicable on MBEs in general, thus also on multinational enterprises as subgroup of MBEs. This paper has been intended as introduction for wider research into optimal taxation with respect to transfer pricing. Therefore the main application of the findings derived in this paper is to support analysis of transfer pricing rules and tax rules design, with respect to international transfer pricing. However further use might be much wider as our conclusions probably would influence design of models of optimal transfer price in presence of taxation, information asymmetry, etc. (which in many cases draw on the marginal cost transfer pricing rule).

\section{References}

[1] Anctil, R. M. - Dutta, S. (1999): Negotiated Transfer Pricing and Divisional vs. Firm-Wide Performance Evaluation. Accounting Review, 1999, vol. 74, no. 1, pp. 87-104. 
Buus, T. - Brada, J.: On the Necessity of Using Average Cost as a Base for Transfer Price.

[2] Baldenius, T. - Melumad, N. D. - Reichelstein, S. J. (2004): Integrating Managerial and Tax Objectives in Transfer Pricing. Accounting Review, 2004, vol. 79, no. 3, pp. 591-615.

[3] Baumol, W.J. - Bradford, D.F. (1970): Optimal Departures from Marginal Cost Pricing. American Economic Review, 1970, vol. 60, no. 3, pp. 265-283.

[4] Cook, P.W. (1955): Decentralization and the Transfer-Price Problem. The Journal of Business, 1955, vol. 28, no. 2, pp. 87-94.

[5] Gatti, J. F. - Grinnell, D. J. - Jensen, O. W. (1997): Replicating a Free Market for Internal Transactions: An Alternative Approach to Transfer Pricing. Journal of Business and Economic Studies, 1997, vol. 3, no. 2, pp. 43-62.

[6] Hirschey, M. (2003): Managerial Economics. Boston, SouthWestern College, 2003.

[7] Hirshleifer, J. (1956): On the Economics of Transfer Pricing. Journal of Business, 1956, vol. 29, no. 3, pp. 172-184.

[8] Hirshleifer, J. (1957): Economics of divisionalized firm. Journal of Business, 1957, vol. 30, no. 2, pp. 96-108.

[9] Lutter, M. et al. (1998): Handbuch der Konzernfinanzierung. Köln, Verlag Dr. Otto Schmidt, 1998.

[10] Miller, B. L. - Buckman, A. G. (1987): Cost Allocation and Opportunity Costs. Management Science, 1987, vol. 33, no. 5, pp. 626-639.

[11] Novotný, F (2008): Tax Optimization of Multinational Firms Through Transfer Pricing: A Survey of Main Theoretical Foundations and Potential Macroeconomic Impacts. Politická ekonomie, 2008, vol. 56, no. 1, pp. 40-53.

[12] OECD (2001): Transfer Pricing Guidelines for Multinational Enterprises and Tax Administrations. Paris, OECD, 2001.

[13] Pappas, J. L. - Brigham, E. F. - Hirschey, M. (1983): Managerial Economics. Chicago, Dryden Press, 1983.

[14] Ronen, J. - McKinney, G. (1970): Transfer Pricing for Divisional Autonomy. Journal of Accounting Research, 1970, vol. 8, no. 1, pp. 99-112. 
[15] Schmalenbach, E. (1909): Über Verrechnungspreise. Zeitschrift für handelswissenschaftliche Forschung, 1909, vol. 3, pp. 165-185.

[16] Soukup, J (2003): Mikroekonomická analýza - vybrané problémy. (in English: Microeconomic Analysis - Selected problems). Slaný, Melandrium, 2003. 

Price.

\title{
On the Necessity of Using Average Cost as a Base for Transfer Price
}

Tomáš BUUS - Jaroslav BRADA

\begin{abstract}
Both older and recent literature on transfer pricing is not unified about the opinion whether optimal transfer price should be equal to marginal cost of supplying company and set by centralized decision (of vertically integrated multibusiness enterprise headquarters) or whether it should be set by negotiation or even set on level of market (arms-length) price. Those, who argue for setting transfer price by negotiation or at the market price base their arguments on market imperfections like information asymmetry, motivation of managers, et cetera. This paper deals inter alia with problem of methodology transfer pricing mathematical modelling. We prove that optimal transfer price should be equal to average cost of the supplying division plus part (or whole) economic profit of the multibusiness enterprise, independent on the market conditions at the market of either intermediate or final product. Setting transfer price on the level of marginal cost is inefficient and would earlier or later lead to loss of multibusiness enterprise's ability to compete its rivals. Applicability of results of our research on multinational enterprises gives us possibility to use it for further research on optimal design of transfer pricing rules setting and of multinationals' taxation.
\end{abstract}

Key words: Multibusiness enterprise; OECD taxation guidelines; Transfer pricing; Vertical integration.

JEL classification: D21, D29, G39. 